\title{
Estimasi Kandungan Degadable Organic Carbon (DOC) pada Sampah Padat Kota yang masuk ke TPA Tanjung Belit di Kota Pasir Pangaraian Provinsi Riau
}

\author{
Faizan Dalilla ${ }^{1}$, Mursyidah Umar' ${ }^{2}$, Abrar Ridwan ${ }^{3}$ \\ ${ }^{1}$ Program Studi Teknik Sipil, Fakultas Teknik, Universitas Islam Riau, Kota Pekanbaru. \\ Email: dalillafaizan@eng.uir.ac.id \\ ${ }^{2}$ Program Studi Teknik Perminyakan, , Fakultas Teknik, Universitas Islam Riau, Kota Pekanbaru. \\ Email: mursyidahumar@eng.uir.ac.id \\ ${ }^{3}$ Program Studi Teknik Mesin, Fakultas Teknik, Universitas Muhammadiyah Riau, Kota Pekanbaru. \\ Email: abrarridwan@yahoo.com
}

\begin{abstract}
Degradable Organic Carbon (DOC) is the important element in forming $\mathrm{CH}_{4}$ in a pile of garbage in the landfill. The calculation of the potential of methane $\left(\mathrm{CH}_{4}\right)$ in the landfill become the basis for control and management of GHG sourced from landfill. Estimated value of the content of DOC used calculating the weight of municipal solid waste that goes into landfill every day, counting the value of the fraction of the composition and content of dry matter of municipal solid waste by 11 components of garbage (food, paper / cardboard, gardens and parks, nappies, wood, textiles, rubber / leather, plastic, glass, metal and sampahlain etc.), to further multiplied by the fraction of a default value content of DOC in each component of trash and garbage in total.

The calculations show that the total weight of waste that goes to landfill every day at $14594.05 \mathrm{~kg} /$ day with the largest waste composition in the form of junk food at $49.54 \%$, followed by plastic waste $(13.76 \%)$ and the smallest is junk metal composition by $1.18 \%$. As for the fraction of the dry matter of the highest value was found in the garbage rubber / leather by $95.31 \%$, followed by wood waste amounted to $78.61 \%$ and the smallest value was found in the garbage nappies by $17.43 \%$ and $21.23 \%$ of food waste. Based on calculations using the value of the total garbage in, the fraction of the composition and the fraction of dry material content and the fraction of DOC.
\end{abstract}

Keywords: DOC, Municipal Waste, Content of waste.

\begin{abstract}
Abstrak
Degradable Organic Carbon (DOC) adalah unsur utama dalam pembentuk $\mathrm{CH}_{4}$ pada tumpukan sampah di TPA. Mengetahui besar kandungan DOC pada sampah padat kota yang masuk ke TPA diperlukan untuk perhitungan potensi metana $\left(\mathrm{CH}_{4}\right)$ yang dapat dihasilkan. Perhitungan potensi metana $\left(\mathrm{CH}_{4}\right)$ di TPA menjadi dasar dalam pengendalian dan pengelolaan GRK yang bersumber dari TPA. Perkiraan nilai kandungan DOC dilakukan dengan menghitung berat sampah padat kota yang masuk ke TPA setiap hari, menghitung nilai fraksi komposisi dan kandungan bahan kering sampah padat kota berdasarkan 11 komponen sampah (makanan, kertas/karton, kebun dan taman, nappies, kayu, tekstil, karet/kulit, plastik, kaca, logam dan sampahlain-lain), untuk selanjutnya dikalikan dengan nilai default fraksi kandungan DOC pada setiap komponen sampah dan total sampah masuk. Hasil perhitungan menunjukkan bahwa total berat sampah yang masuk ke TPA setiap hari sebesar 14.594,05 $\mathrm{kg} /$ hari dengan komposisi sampah terbesar berupa sampah makanan sebesar 49.54\% diikuti sampah plastik (13.76\%) dan komposisi terkecil adalah sampah logam sebesar 1,18\%. Sedangkan untuk fraksi bahan kering nilai tertinggi ditemukan pada sampah karet/kulit sebesar 95,31\%, diikuti oleh sampah kayu sebesar 78,61\% dan nilai terkecil ditemukan pada sampah nappies sebesar 17,43\% dan sampah makanan sebesar 21,23\%. Berdasarkan hasil perhitungan menggunakan nilai total sampah masuk, fraksi komposisi dan fraksi kandungan bahan kering dan fraksi DOC default perkomponen sampah, maka didapatkan nilai kandungan DOC pada sampah padat kota yang masuk ke TPA tanjung belit sebesar $0.585 \mathrm{Gg} C$.
\end{abstract}

Kata Kunci: DOC, Sampah Padat Kota, Komposisi Sampah, Kandungan Bahan Kering.

\section{PENDAHULUAN}

Gas rumah kaca (GRK) adalah istilah untuk gas-gas yang memiliki efek rumah kaca, seperti karbon dioksida $\left(\mathrm{CO}_{2}\right)$, metana $\left(\mathrm{CH}_{4}\right)$, klorofluorokarbon $(\mathrm{CFC})$, nitrogen oksida $(\mathrm{NOx})$, ozon $\left(\mathrm{O}_{3}\right)$ dan uap air $\left(\mathrm{H}_{2} \mathrm{O}\right)$. Besaran efek rumah kaca dari masing-masing gas tersebut berbeda-beda. Salah satu yang 
memiliki efek rumah kaca yang tiggi adalah Metana $\left(\mathrm{CH}_{4}\right)$. Unsur ini memiliki efek 20-30 kali lebih besar dibanding karbon dioksida. Besarnya efek rumah kaca yang ditimbulkan oleh keberadaan Metana $\left(\mathrm{CH}_{4}\right)$ di atmosfer menjadi dasar dilakukannya identifikasi sumber aktifitas yang berkontribusi dalam meningkatkan konsentrasi gas ini di udara.

Salah satu penyumbang Metana $\left(\mathrm{CH}_{4}\right)$ adalah sampah padat kota. Aktifitas pemrosesan sampah padat kota di TPA terutama yang bersistem sanitary landfill berkontribusi dalam menghasilkan gas tersebut. Metana $\left(\mathrm{CH}_{4}\right)$ merupakan gas yang terbentuk dari proses dekomposisi anaerob sampah organik. Total produksi tergantung kepada komposisi sampah. Masing-masing komponen sampah memiliki karakteristik yang berbeda. Karakteristik sampah mencakup: (a) Degradable Organic Carbon (DOC), (b) Fossil Carbon, dan (c) faktor koreksi penyetaraan (corresponding) emisi $\mathrm{CH}_{4}(\mathrm{MCF})$. DOC adalah karakteristik limbah yang menentukan besarnya gas $\mathrm{CH}_{4}$ yang dapat terbentuk selama proses degradasi komponen organik/karbon yang terdapat pada limbah. Besarnya DOC bergantung kepada komposisi (\% berat) dan dry matter content (kandungan bahan kering) masing-masing komponen sampah.

TPA Tanjung Belit adalah salah satu TPA yang beroperasi di kabupaten Rokan Hulu, Provinsi Riau. TPA ini melayani sampah padat yang berasal dari Kawasan Perkotaan Pasir Pangaraian yang merupakan pusat pemerintahan kabupaten Rokan Hulu. TPA ini baru beroperasi pada tahun 2012, sehingga jumlah timbunan sampah yang ada di TPA ini relatif masih sedikit. Pada awal tahun 2015, area yang terpakai hanya meliputi $20 \%$ dari total bangunan landfill yang ada. Berdasarkan kondisi tersebut, pendataan dan estimasi kandungan DOC untuk TPA ini menjadi penting sebagai bagian dari estimasi potensi metana $\left(\mathrm{CH}_{4}\right)$ yang menjadi dasar dalam pengelolaan dan pemanfaatan gas tersebut serta sebagai nbagian dari kegiatan inventarisasi GRK di Provinsi Riau.

Maka dari itu, kegiatan penelitian terkait perkiraan kandungan DOC berdasarkan perhitungan berat sampah padat yang masuk ke TPA dan perhitungan komposisi sampah padat serta kandungan bahan kering sampah menjadi penting untuk dilakukan agar dapat mengestimasi total kandungan DOC sampah yang masuk ke TPA. Hasil estimasi kandungan DOC akan menjadi dasar dalam memperkirakan potensi $\mathrm{CH}_{4}$ dari TPA. Data potensi $\mathrm{CH}_{4}$ akan sangat bermanfaat dalam menyusun tindakan lebih lanjut baik terkait pengurangan emisi GRK dan juga terkait kemungkinan pemanfaatan $\mathrm{CH}_{4}$ sebagai alternatif sumber energi.

Permasalahan yang terjadi pada inventarisasi GRK dari sektor sampah padat kota adalah sulitnya mengestimasi potensi $\mathrm{CH}_{4}$ di TPA karena minimnya ketersediaan data aktifitas sampah padat. Jumlah sampah masuk pada TPA tidak dihitung secara detail. Penghitungan yang ada selama ini hanya dilakukan secara sederhana dengan menghitung jumlah truk yang masuk ke TPA. Idealnya perhitungan total sampah masuk ke TPA dilakukan berdasarkan berat sampah yang dihasilkan dari penimbangan sampah menggunakan jembatan timbang di TPA atau dapat pula dilakukan dengan estimasi berat berdasarkan volume dengan menggunakan bulk density. Sedangkan data terkait komposisi dan kandungan bahan kering sama-sekali tidak ditemukan. Mengingat kedua data ini memerlukan kegiatan yang lebih kompleks dibanding pencatatan sampah masuk.

Kegiatan penelitian ini bertujuan untuk memperkirakan total kandungan DOC pada sampah yang masuk ke ke TPA Tanjung Belit, Kota Pasir Pangaraian Kabupaten Rokan Hulu Provinsi Riau dengan melakukan pengukuran terhadap jumlah sampah masuk, komposisi sampah, kandungan bahan kering berdasarkan komponen dan perhitungan fraksi DOC sampah di TPA ini. Hasil penelitian diharapkan dapat menjadi dasar dalam memperkirakan jumlah potensi $\mathrm{CH}_{4}$ yang dihasilkan TPA Tanjung Belit ysng nantinya hasil perkiraan tersebut menjadi dasar kebijakan dalam pengelolaan dan pemanfaatan gas tersebut demi kepentingan umum.

\section{METODE}

Penelitian ini dilaksanakan dengan mengacu pada pedoman survei perhitungan komposisi Sampah Padat dan Kandungan Bahan Kering yang dikeluarkan oleh Kementerian Lingkungan Hidup dan Kehutanan Indonesia (KLHK RI) . Sedangkan perhitungan jumlah faktor emisi dari sampah padat kota dalam 
penelitian ini mengacu pada General Guidance and Reporting for National Greenhouse Gas Inventories yang dikeluarkan oleh IPCC tahun 2006.

Aktivitas penelitian dibagi menjadi empat tahapan sebagai berikut : 1) Mengukur berat dan volume, 2) Sampling, 3) Analisa sampel di Laboratorium dan 4) Analisa data.

\subsection{Mengukur Berat dan Volume Sampah}

Mengukur berat dan volume sampah padat yang masuk ke TPA dengan cara penimbangan dan dibagi berdasarkan 3 daerah sumber (kawasan permukiman, kantor dan komersial). Jika pada TPA tidak terdapat jebatan timbang, maka perhitungan berat dapat menggunakan bulk density dari TPA yang memiliki jembatan timbang. Pemilihan TPA didasarkan pada kesamaan karakteristik kota mengingat sampah padat yang dihasilkan suatu kota sangat bervariasi sebagai konsekuensi dari musim, gaya hidup, demografis, geografis, dan dampak perundang-undangan (Gidarakos, 2005). oleh Data tersebut digunakan untuk menghitung persentase berat sampah padat dari masing-masing sumber dibandingkan dengan total sampah padat yang masuk dalam satu hari. Persentase ini selanjutnya akan digunakan dalam penentuan volume sample. Selain melakukan penimbangan, dilakukan juga pengukuran volume dari seluruh sampah padat berdasarkan sumber sampah.

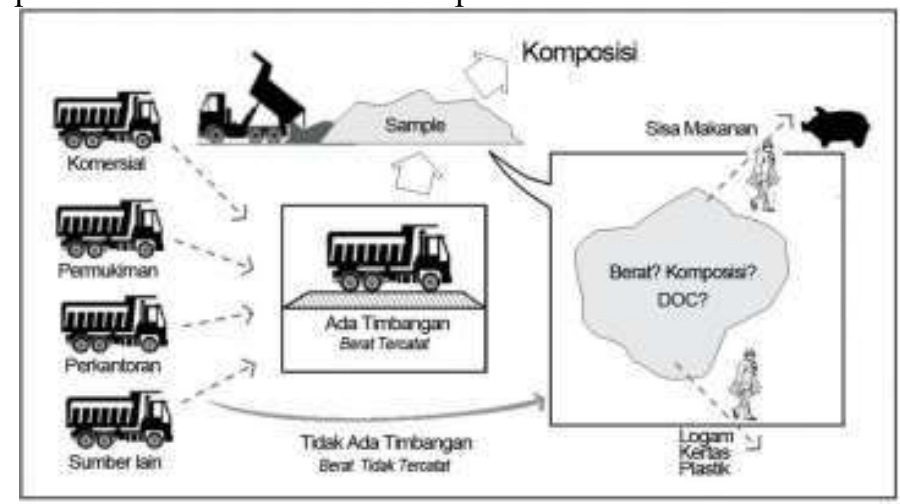

Gambar 1: Situasi Pembuangan Sampah Di TPA

\subsection{Sampling Sampah dan Perhitungan Komposisi Sampah}

Kegiatan sampling dilakukan terkait perhitungan komposisi. Volume sampel sampah yang diambil dari tiap TPA ditetapkan sebesar $1 \mathrm{~m}^{3}$. Sampel harus mewakili 3 daerah sumber. Setiap sumber diwakili dengan volume yang dihitung berdasarkan persentase berat yang telah diperoleh pada kegiatan sebelumnya. Sampling dilakukan 4 kali yaitu dua kali di musim panas dan dua kali di musim hujan agar dapat mewakili setiap musim. Pengambilan sampel pada setiap musim dilaksanakan pada hari Senin yang mewakili sampah akhir pekan dan hari Kamis untuk mewakili hari kerja. Selanjutnya sampel sampah padat dikelompokkan menjadi 11 komponen: 1) makanan, 2) kebun dan taman, 3) kayu, 4) kertas dan kardus, 5) tekstil, 6) Nappies, 7) karet dan kulit, 8) plastik, 9) logam , 10) kaca, 11) dan lainlain (IPCC $2006 \mathrm{GL}$ ) yang masing-masing ditimbang untuk mendapatkan berat basah masing-masing komponen. Fraksi komposisi sampah merupakan hasil perbandingan antara berat basah masing-masing komponen dengan berat total sampling.

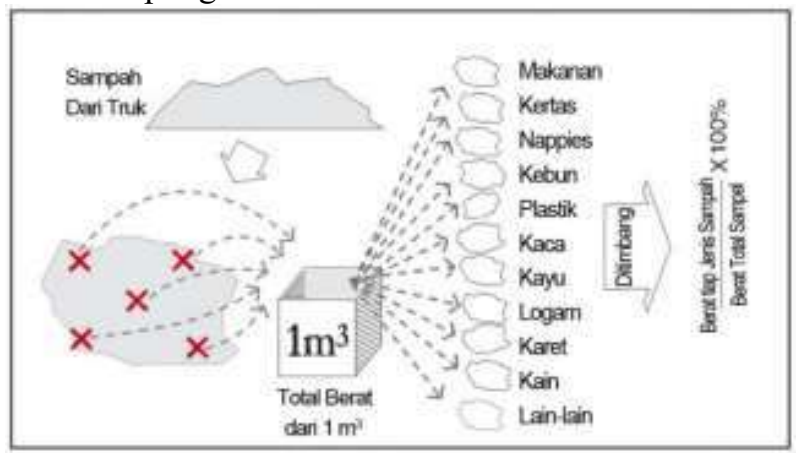

Gambar 2: Proses Sampling Sampah dan Perhitungan Fraksi Komposisi 
Selain itu, untuk mendapatkan data yang lebih akurat dalam memperkirakan berat total sampah padat yang masuk ke TPA, diperhitungkan pula seberapa besar sampah padat yang diambil pemulung untuk didaur ulang. Persentase jumlah sampah padat yang diambil pemulung akan menjadi faktor koreksi dalam menghitung berat total sampah padat (yang masuk ke TPA). Volume dan jenis Sampah Padat yang dikumpulkan oleh pemulung dapat diidentifikasi dengan cara mewawancarai pemulung dan kolektor di sekitar TPA.

\subsection{Pengeringan Sampel di laboratorium}

Sampel untuk penentuan kandungan bahan kering diambil dari sampel yang telah digunakan dalam penentuan komposisi sampah padat. Penentuan kandungan bahan kering dilakukan menggunakan metode Gravimetry per komponen sampah padat. Pengukuran hanya dilakukan pada komponen sampah yang memiliki kandungan air, Mengingat tidak semua komponen sampah yang memiliki kandungan air signifikan. Data default IPCC GL 2006 (Tabel 1) menunjukkan bahwa kandungan bahan kering sampah plastik, kaca, dan logam adalah $100 \%$, dengan demikian, penentuan isi bahan kering hanya diterapkan untuk sampah yang termasuk komponen berikut : (1) makanan; (2) Kayu; (3) Kebun dan taman; (4) Kertas dan kertas karton; (5) Nappies; (6) Kain dan produk tekstil; dan (7) karet dan kulit.

Tabel 1: Nilai Default DOC untuk Fraksi Sampah Padat Kota

\begin{tabular}{|c|c|c|c|c|c|c|c|c|c|}
\hline \multirow[t]{2}{*}{$\begin{array}{l}\text { Komponen } \\
\text { MSW }\end{array}$} & \multirow{2}{*}{$\begin{array}{c}\begin{array}{c}\text { Kandungan } \\
\text { Bahan } \\
\text { Kering (\%) } \\
\text { Berat Basah }\end{array} \\
\text { Default } \\
\end{array}$} & \multicolumn{2}{|c|}{$\begin{array}{c}\text { Kandungan } \\
\text { DOC (\%) berat } \\
\text { basah }\end{array}$} & \multicolumn{2}{|c|}{$\begin{array}{c}\text { Kandungan } \\
\text { DOC (\%) berat } \\
\text { kering }\end{array}$} & \multicolumn{2}{|c|}{$\begin{array}{c}\text { Total } \\
\text { Kandungan } \\
\text { Karbon ( \% ) } \\
\text { Berat Kering } \\
\end{array}$} & \multicolumn{2}{|c|}{$\begin{array}{l}\text { Fossil Carbon } \\
\text { Fraction in \% of } \\
\text { total carbon }\end{array}$} \\
\hline & & Default & Range & $\begin{array}{c}\text { Defaul } \\
t\end{array}$ & Range & $\begin{array}{c}\text { Defaul } \\
t\end{array}$ & Range & $\begin{array}{c}\text { Defaul } \\
t\end{array}$ & Range \\
\hline Kertas/Karton & 90 & 40 & $36-45$ & 44 & $40-50$ & 46 & $42-50$ & 1 & $0-5$ \\
\hline Tekstil & 80 & 24 & $20-40$ & 30 & $25-50$ & 50 & $25-50$ & 20 & $0-50$ \\
\hline Sampah makanan & 40 & 15 & $8-20$ & 38 & $20-50$ & 38 & $20-50$ & - & - \\
\hline Kayu & $85^{4}$ & 43 & $39-46$ & 50 & $46-54$ & 50 & $46-54$ & - & - \\
\hline $\begin{array}{l}\text { Halaman dan } \\
\text { Taman Waste }\end{array}$ & 40 & 20 & $18-22$ & 49 & $45-55$ & 49 & $45-55$ & 0 & 0 \\
\hline Nappies & 40 & 24 & $18-32$ & 60 & $44-80$ & 70 & $54-90$ & 10 & 10 \\
\hline Karet dan Kulit & 84 & $(39)^{5}$ & $(39)^{5}$ & $(47)^{5}$ & $(47) 5$ & 67 & 67 & 20 & 20 \\
\hline Plastic & 100 & - & - & - & - & 75 & $67-85$ & 100 & $95-100$ \\
\hline Logam & 100 & - & - & - & - & NA & NA & NA & NA \\
\hline Kaca & 100 & - & - & - & - & NA & NA & NA & NA \\
\hline Sampah Lainnya & 90 & - & - & - & - & 3 & $0-5$ & 100 & $50-100$ \\
\hline
\end{tabular}

Berat sampel untuk penentuan isi bahan kering dari komponen sampah adalah sekitar $\pm 1 \mathrm{~kg}$ sampel yang diambil dari hasil kegiatan penentuan komposisi sampah dengan pengurangan berat sampel. Pengurangan berat dari sampel untuk masing-masing komponen dilakukan dengan metode "quartering". Sampel diangkut ke laboratorium menggunakan kantong sampel terpisah. Selanjutnya sampel sampah padat dikeringkan dengan menggunakan oven untuk menghilangkan kandungan air di dalamnya (Gravimetry). Setelah kering, setiap sampel akan ditimbang untuk mendapatkan Kandungan Bahan Kering dari setiap komponen. Fraksi Kandungan Bahan Kering adalah perbandingan antara berat kering dan berat basah dari setiap komponen.

\subsection{Analisa Data}

Analisa data dilakukan terhadap seluruh hasil pengukuran berat dan volume total sampah masuk ke TPA, data komposisi dan kandungan bahan kering komponen. Perhitungan kandungan DOC dilakukan dengan mengalikan fraksi komposisi, kandungan bahan kering dan nilai default kandungan DOC setiap komponen (IPCC GL2006) untuk mendapatkan fraksi DOC (Rumus 1). Sedangkan total kandungan DOC didapatkan dengan mengalikan fraksi DOC yang sudah didapatkan dengan total berat sampah yang masuk dalam 1 tahun. 
Keterangan:

$$
\text { Fraksi DOC }=\sum\left(\mathrm{DOCi} \bullet \mathrm{W} \bullet \mathrm{W}_{\mathrm{i}}\right)
$$

DOCi merupakan fraksi default kandungan DOC untuk komponen i

W merupakan fraksi berat basah (Komposisi) untuk komponen i

Wi merupakan fraksi kandungan bahan kering untuk komponen $\mathrm{i}$

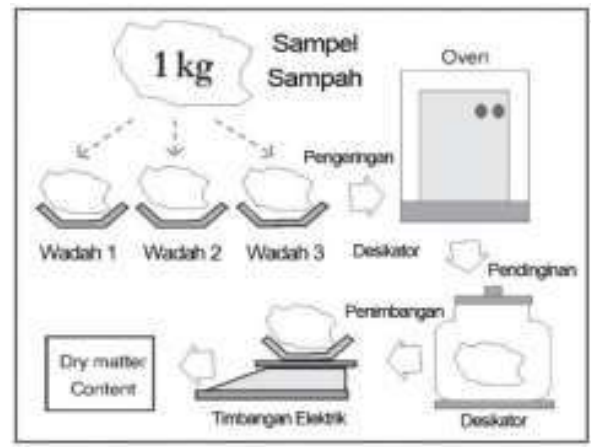

Gambar 3: Proses Penentuan Kandungan Bahan Kering

\section{Hasil dan Pembahasan}

Berikut ini merupakan hasil yang didapatkan dari penelitian ini yang dilakukan di TPA Tanjung Belit, Kabupaten Rokan Hulu, Provinsi Riau.

\subsection{Gambaran Umum}

TPA Tanjung Belit terletak di Desa Tanjung Belit, Kabupaten Rokan Hulu. Berada pada kawasan perkotaan Pasir Pangaraian yang merupakan pusat pemerintahan Kabupaten Rokan Hulu, kabupaten yang memiliki luas wilayah sekitar 7.462,18 km. Perbatasan Kabupaten Rokan Hulu di utara dengan Kabupaten Rokan Hilir dan Provinsi Sumatera Utara, di selatan dengan Kecamatan XIII Koto Kampar dan Bangkinang Barat Kabupaten Kampar, di barat dengan Provinsi Sumatera Barat, dan di timur dengan Kecamatan Tapung dan Kecamatan Bangkinang, Kabupaten Kampar.

Wilayah Kabupaten Rokan Hulu dilintasi 2 sungai besar dan beberapa sungai kecil. Salah satunya adalah Sungai Rokan yan memiliki panjang sekitar 100 kilometer dengan rata-rata kedalaman sebesar 6 meter dan lebar adalah 92 meter. Sementara hilir sungai berada di wilayah Kabupaten Rokan Hilir.

Kabupaten Rokan Hulu memiliki iklim tropis. Suhu maksimum adalah sekitar $31^{\circ} \mathrm{C}-32^{\circ} \mathrm{C}$. Jumlah hari hujan tertinggi pada tahun 2014 terjadi pada bulan November, begitu pula dengan curah hujan tertinggi juga terjadi pada bulan November.

Jumlah penduduk kabupaten Rokan Hulu pada tahun 2014 tercatat sebesar 568.576 jiwa, yang terbagi atas 294,729 jiwa laki-laki dan 273,847 jiwa. Kepadatan penduduk pada tahun 2014 sebesar 76 jiwa/km2. Kecamatan dengan kepadatan tertinggi di Kabupaten Rokan Hulu adalah kecamatan Ujung Batu. Kota Pasir Pangaraian di Kecamatan Rambah menjadi ibukota Kabupaten Rokan Hulu, yang ekonomi penduduknya bertumpu pada sektor perkebunan dan pertanian.

TPA Tanjung Belit memiliki total luas lahan 5 ha yang dialokasikan untuk penimbunan sampah, dan seluas 2 ha telah terpakai. TPA Tanjung Belit dioperasikan sejak 2012. TPA ini melayani sampah padat dari 2 kecamatan; Rambah dan Rambah Samo dengan jumlah penduduk pada dua kecamatan ini sebesar 79.16o jiwa. Mengingat minimnya jumlah armada yang tersedia, pengangkutan sampah diprioritaskan pada kawasan pasar, komplek perkantoran dan beberapa kawasan permukiman pada jalan-jalan utama. Bahkan, pada Kecamatan Rambah Samo, sampah yang diangkut hanya sampah yang berasal dari kawasan fasilitas umum milik pemerintah seperti perkantoran dan bandara.

TPA Tanjung Belit beroperasi dengan sistem Sanitary Landfill yang didukung konstruksi standar, dimana dasar area ladnfill telah dilapisi lapisan geotextil dan dilengkapi pipa penangkapan gas metan 
(methane capturing). Operasional TPA Tanjung Belit juga didukung oleh ketersediaan 3 unit alat berat berupa 2 unit escavator dan 1 unit buldozer namun belum dilengkapi dengan jembatan timbang.

\subsection{Volume dan Berat Sampah Masuk}

Perhitungan jumlah sampah padat yang masuk ke TPA Tanjung Belit dilaksanakan berdasarkan hasil estimasi volume karena tidak ada jembatan timbang. Estimasi volume dilakukan dalam empat hari survei ( 2 hari di musim panas mewakili hari kerja dan hari libur, 2 hari di musim hujan mewakili hari kerja dan hari libur).

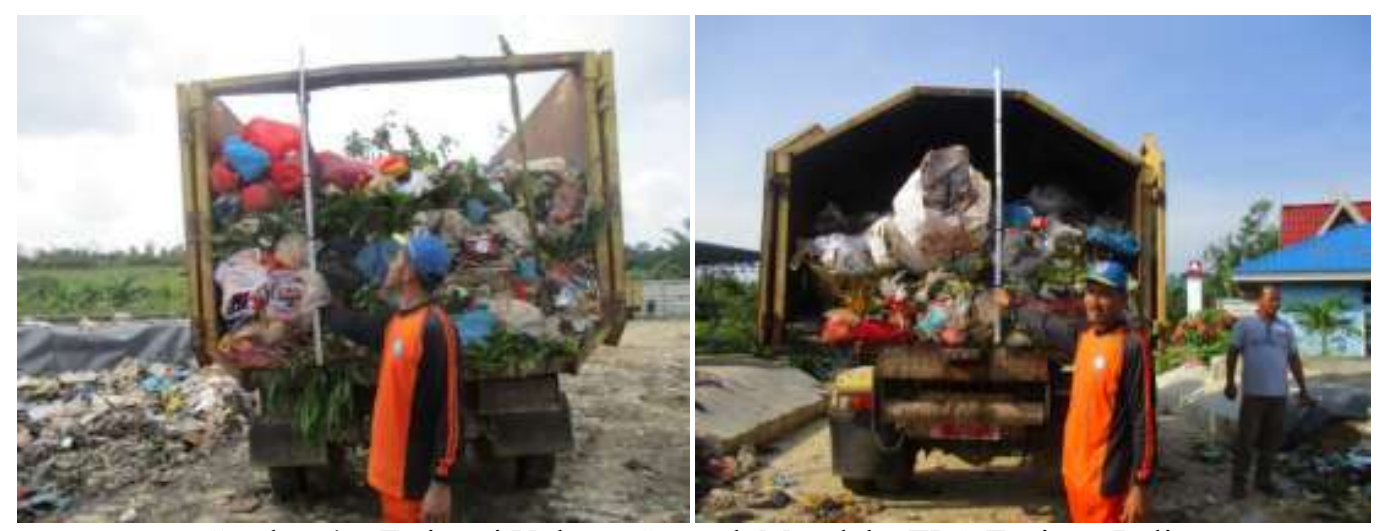

Gambar 4: Estimasi Volume Sampah Masuk ke TPA Tanjung Belit

Berat sampah diperkirakan melalui perkalian total volume hasil estimasi dan Bulk Density. Perhitungan tersebut menggunakan Bulk Density dari sampah yang ada di TPA lain yang memiliki jembatan timbang dan memiliki karakteristik sampah yang mirip dengan sampah pada lokasi studi. Berdasarkan pertimbangan jarak, kondisi iklim dan karakteristik kegiatan ekonomi masyarakat, maka untuk perhitungan berat sampah di TPA Tanjung Belit, digunakan bulk density yang berasal dari TPA Bangkinang yang telah diurvey dan dihitung sebelumnya. Survey dan perhitungan bulk density di TPA Bangkinang menggunakan skema hari survey yang mewakili musim dan hari kerja dan libur.

Berdasarkan hasil survei dan perhitungan, diperoleh volume tertinggi sampah masuk ke TPA Tanjunga Belit ditemukan pada hari libur di musim hujan yaitu sebesar $45,86 \mathrm{~m}^{3}$. Volume sampah padat rata-rata yang masuk selama 4 hari kegiatan survei adalah sebesar $42,44 \mathrm{~m}^{3} /$ hari dan setelah dilakukan konversi volume ke berat, maka berat sampah padat rata-rata yang masuk ke TPA Tanjung Belit sebesar $14.592,24 \mathrm{~kg} / \mathrm{hari}$.

Tabel 2: Sampah Padat Kota yang Masuk ke TPA Tanjung Belit

\begin{tabular}{|c|c|c|c|}
\hline Musim/Hari & $\begin{array}{l}\text { Volume } \\
\text { Sampah } \\
\left(\mathbf{m}^{3} / \text { hari) }\right.\end{array}$ & $\begin{array}{l}\text { Bulk Density } \\
\text { (Kg/m3) }\end{array}$ & $\begin{array}{c}\text { Berat Sampah } \\
\text { (Kg/hari) }\end{array}$ \\
\hline \multicolumn{4}{|l|}{ Musim Panas } \\
\hline 1 Hari Kerja & 45,36 & 344,86 & $15.642,31$ \\
\hline 2 Hari Libur & 37,53 & 319,49 & $11.991,88$ \\
\hline \multicolumn{4}{|l|}{ Musim Hujan } \\
\hline 1 Hari Kerja & 41,01 & 378,02 & $15.502,15$ \\
\hline 2 Hari Libur & 45,86 & 332,33 & $15.239,87$ \\
\hline Rata-rata & 42,44 & & $14.594,05$ \\
\hline
\end{tabular}

\subsection{Komposisi Sampah}

Komposisi sampah padat kota diperoleh dari pemilahan setiap sampel sampah yang dibagi menjadi sebelas komponen yang berbeda. Sampel sampah diambil dari tumpukan sampah yang baru diturunkan dari kendaraan pengangkut sampah. Sampel ditentukan berdasarkan sumber sampah. Sumber sampah dikelompokkan dalam tiga jenis yaitu kawasan permukiman, kawasan pasar dan kawasan perkantoran. Pengambilan sampel sampah mewakili masing-masing sumber tersebut. 


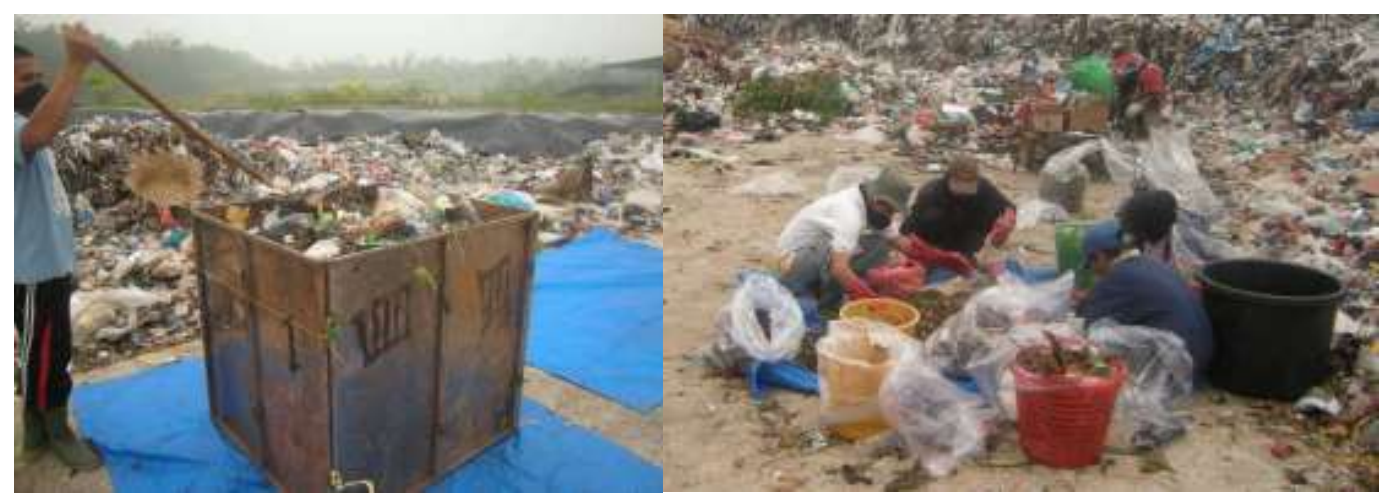

Gambar 5: Pengambilan dan Pemilahan Sampel Sampah Berdasarkan Komponen

Selanjutnya dilakukan penimbangan pada sampel sampah hasil pemilahan hingga diperoleh persentase berat masing-masing komponen. Ditemukan bahwa sampah makanan merupakan komponen dengan fraksi tertinggi dari total sampah masuk ke TPA Tanjung Belit (49.54\%), sedangkan sampah logam merupakan fraksi terkecil (1,18\%). Rincian mengenai komposisi sampah padat kota di TPA Tanjung Belit, dapat dilihat pada Tabel 3.

Tabel 3: Komposisi Sampah Padat Kota di TPA Tanjung Belit

\begin{tabular}{|c|c|c|c|c|c|c|c|}
\hline \multirow[b]{2}{*}{ No } & \multirow[b]{2}{*}{ Komponen Sampah } & \multicolumn{2}{|c|}{ Musim Panas } & \multicolumn{2}{|c|}{ Musim Hujan } & \multirow{2}{*}{$\begin{array}{c}\text { Total } \\
\text { Berat Sampel } \\
(\mathrm{Kg})\end{array}$} & \multirow{2}{*}{$\begin{array}{c}\text { Berat } \\
\text { (\%) }\end{array}$} \\
\hline & & $\begin{array}{l}\text { Hari kerja } \\
(\mathbf{K g})\end{array}$ & $\begin{array}{c}\text { Hari Libur } \\
(\mathrm{Kg})\end{array}$ & $\begin{array}{c}\text { Hari kerja } \\
(\mathbf{K g})\end{array}$ & $\begin{array}{c}\text { Hari Libur } \\
(\mathrm{Kg})\end{array}$ & & \\
\hline 1 & Makanan & 99,35 & 105,06 & 103,00 & 133,90 & 441,31 & 49,54 \\
\hline 2 & Kertas/Karton & 21,10 & 21,75 & 36,60 & 23,20 & 102,65 & 11,52 \\
\hline 3 & Kebun dan Taman & 9,40 & 12,60 & 18,20 & 7,40 & 47,60 & 5,34 \\
\hline 4 & Nappies & 12,40 & 14,85 & 7,40 & 20,70 & 55,35 & 6,21 \\
\hline 5 & Kayu & 4,70 & 3,35 & 7,50 & 6,90 & 22,45 & 2,52 \\
\hline 6 & Tekstil & 5,40 & 6,30 & 14,10 & 3,50 & 29,30 & 3,29 \\
\hline 7 & Karet/Kulit & 3,20 & 1,35 & 8,20 & 2,70 & 15,45 & 1,73 \\
\hline 8 & Plastik & 37,00 & 3,80 & 35,30 & 17,50 & 122,60 & 13,76 \\
\hline 9 & Kaca & 4,10 & 2,10 & 5,00 & 5,40 & 16,60 & 1,86 \\
\hline 10 & Logam & 1,25 & 1,50 & 4,70 & 3,10 & 10,55 & 1,18 \\
\hline 11 & Lain-lain & 7,75 & 8,94 & 7,10 & 3,10 & 26,89 & 3,02 \\
\hline & Total & & & & & 890,75 & 100,00 \\
\hline
\end{tabular}

Mengingat adanya aktifitas pemulung yang mengambil sampah di TPA Tanjung Belit, maka dapat dipastikan terjadi pengurangan volume dan berat sampah di TPA Tanjung Belit setiap hari. Berdasarkan hasil wawancara terhadap pemulung, diketahui ada 2 jenis sampah yang diambil yaitu kertas/karton dan plastik. Berdasarkan hasil wawancara didapatkan jumlah sampah yang diambil pemulung yaitu karton dengan berat rata-rata $10 \mathrm{~kg} /$ hari dan plastik sebesar $100 \mathrm{~kg} / \mathrm{hari}$. Persentase berat sampah yang diambil pemulung adalah $0,75 \%$.

Tabel 4: Data Berat Sampah Diambil Pemulung Berdasarkan Komponen

\begin{tabular}{|c|c|c|c|c|}
\hline \multirow[t]{2}{*}{ No } & \multirow[t]{2}{*}{ Komponen } & $\begin{array}{c}\text { Berat sampah yang } \\
\text { diambil (Kg/hari) }\end{array}$ & $\begin{array}{c}\text { Berat total sampah } \\
\text { masuk TPA (kg/hari) }\end{array}$ & $\begin{array}{c}\text { Berat sampah yang } \\
\text { diambil }(\%)\end{array}$ \\
\hline & & $\mathrm{a}$ & $\mathrm{b}$ & $\mathrm{c}=\mathrm{a} / \mathrm{b} \times 100 \%$ \\
\hline 1 & Makanan & 0,00 & $14.594,05$ & 0,00 \\
\hline 2 & Kertas/Karton & 10,00 & & 0,07 \\
\hline 3 & Kebun dan Taman & 0,00 & & 0,00 \\
\hline 4 & Nappies & 0,00 & & 0,00 \\
\hline 5 & Kayu & 0,00 & & 0,00 \\
\hline 6 & Tekstil & 0,00 & & 0,00 \\
\hline
\end{tabular}




\begin{tabular}{|c|c|c|c|c|}
\hline \multirow[t]{2}{*}{ No } & \multirow[t]{2}{*}{ Komponen } & $\begin{array}{c}\text { Berat sampah yang } \\
\text { diambil (Kg/hari) }\end{array}$ & $\begin{array}{c}\text { Berat total sampah } \\
\text { masuk TPA (kg/hari) }\end{array}$ & $\begin{array}{c}\text { Berat sampah yang } \\
\text { diambil }(\%)\end{array}$ \\
\hline & & $\mathrm{a}$ & $\mathrm{b}$ & $\mathrm{c}=\mathrm{a} / \mathrm{b} \times 100 \%$ \\
\hline 7 & Karet/Kulit & 0,00 & & 0,00 \\
\hline 8 & Plastik & 100,00 & & 0,69 \\
\hline 9 & Kaca & 0,00 & & 0,00 \\
\hline 10 & Logam & 0,00 & & 0,00 \\
\hline 11 & Lain-lain & 0,00 & & 0,00 \\
\hline & Total & 110,00 & & $\mathbf{0 , 7 5}$ \\
\hline
\end{tabular}

Terkait perhitungan untuk mendapatkan fraksi DOC sampah masuk ke TPA Tanjung Belit, maka persentase berat sampah yang diambil pemulung berdasarkan komponen seperti yang telah diuraikan sebelumnya digunakan sebagai faktor koreksi terhadap persentase berat sampah yang masuk ke TPA. Hasil pengurangan terhadap total sampah masuk menggunakan nilai faktor koreksi ditunjukkan dalam tabel 5 .

Tabel 5: Faktor Koreksi Sampah yang Masuk di TPA Tanjung Belit

\begin{tabular}{rlrrr}
\hline No & Komponen Sampah & Berat (\%) & Correction Factor (\%) & Berat Net (\%) \\
& & & & \\
\hline 1 & Makanan & 49,54 & 0,00 & 49,54 \\
2 & Kertas/Karton & 11,52 & 0,07 & 11,46 \\
3 & Kebun dan Taman & 5,34 & 0,00 & 5,34 \\
4 & Nappies & 6,21 & 0,00 & 6,21 \\
5 & Kayu & 2,52 & 0,00 & 2,52 \\
6 & Tekstil & 3,29 & 0,00 & 3,29 \\
7 & Karet/Kulit & 1,73 & 0,00 & 1,73 \\
8 & Plastik & 13,76 & 0,69 & 13,08 \\
9 & Kaca & 1,86 & 0,00 & 1,86 \\
10 & Logam & 1,18 & 0,00 & 1,18 \\
11 & Lain-lain & 3,02 & 0,00 & 3,02 \\
\hline \multicolumn{2}{c}{ Total } & $\mathbf{1 0 0 , 0 0}$ & $\mathbf{0 , 7 5}$ & $\mathbf{9 9 , 2 5}$ \\
\hline
\end{tabular}

\subsection{Kandungan Bahan Kering}

Kandungan bahan kering suatu komponen sampah dihitung berdasarkan rasio berat kering terhadap berat basah suatu komponen sampah. Perhitungan dilakukan hanya pada 7 komponen sampah (makanan, kertas/karton, kebun/taman, nappies, kayu, tekstil dan karet/kulit). Sedangkan 4 jenis komponen (plastik, logam, kaca dan lain-lain) tidak dilakukan pengeringan karena nilai kandungan bahan kering komponen tersebut adalah 100\% (IPCC 2006GL). Hasil perhitungan menunjukkan fraksi kandungan bahan kering tertinggi adalah sampah karet/kulit $(95,31 \%)$, sedangkan fraksi terkecil adalah sampah nappies $(17,43 \%)$. Fraksi kandungan bahan kering akan digunakan untuk menghitung fraksi DOC.

Tabel 6: Fraksi Kandungan Bahan Kering Sampah di TPA Tanjung Belit

\begin{tabular}{|c|c|c|c|c|c|c|c|c|c|c|}
\hline \multirow[b]{3}{*}{ No } & \multirow{3}{*}{$\begin{array}{c}\text { Komponen } \\
\text { sampah }\end{array}$} & \multicolumn{4}{|c|}{ Musim Panas } & \multicolumn{4}{|c|}{ Musim Hujan } & \multirow{3}{*}{$\begin{array}{c}\text { Kandugan } \\
\text { Bahan } \\
\text { Kering } \\
(\%)\end{array}$} \\
\hline & & \multicolumn{2}{|c|}{ Hari Kerja } & \multicolumn{2}{|c|}{ Hari Libur } & \multicolumn{2}{|c|}{ Hari Kerja } & \multicolumn{2}{|c|}{ Hari Libur } & \\
\hline & & $\begin{array}{c}\text { Berat } \\
\text { Basah } \\
\text { (g) }\end{array}$ & $\begin{array}{l}\text { Berat } \\
\text { kering } \\
\text { (g) }\end{array}$ & $\begin{array}{c}\text { Berat } \\
\text { Basah } \\
\text { (g) }\end{array}$ & $\begin{array}{c}\text { Berat } \\
\text { kering } \\
\text { (g) }\end{array}$ & $\begin{array}{c}\text { Berat } \\
\text { Basah } \\
\text { (g) }\end{array}$ & $\begin{array}{l}\text { Berat } \\
\text { kering } \\
\text { (g) }\end{array}$ & $\begin{array}{c}\text { Berat } \\
\text { Basah } \\
(\mathrm{g})\end{array}$ & $\begin{array}{c}\text { Berat } \\
\text { Kering } \\
\text { (g) }\end{array}$ & \\
\hline 1 & Makanan & 333,71 & 83,60 & 333,29 & 62,77 & 332,94 & 103,24 & 333,3 & 33,42 & 21,23 \\
\hline 2 & Kertas/Karton & 333,28 & 143,57 & 333,33 & 266,01 & 333,81 & 214,91 & 333,1 & 157,58 & 58,65 \\
\hline 3 & Kebun dan aman & 333,32 & 111,65 & 333,19 & 147,41 & 333,50 & 158,22 & 333,5 & 136,43 & 41,52 \\
\hline
\end{tabular}




\begin{tabular}{|c|c|c|c|c|c|c|c|c|c|c|}
\hline \multirow[b]{3}{*}{ No } & \multirow[b]{3}{*}{$\begin{array}{c}\text { Komponen } \\
\text { sampah }\end{array}$} & \multicolumn{4}{|c|}{ Musim Panas } & \multicolumn{4}{|c|}{ Musim Hujan } & \multirow{3}{*}{$\begin{array}{c}\text { Kandugan } \\
\text { Bahan } \\
\text { Kering } \\
(\%)\end{array}$} \\
\hline & & \multicolumn{2}{|c|}{ Hari Kerja } & \multicolumn{2}{|c|}{ Hari Libur } & \multicolumn{2}{|c|}{ Hari Kerja } & \multicolumn{2}{|c|}{ Hari Libur } & \\
\hline & & $\begin{array}{c}\text { Berat } \\
\text { Basah } \\
\text { (g) }\end{array}$ & $\begin{array}{c}\text { Berat } \\
\text { kering } \\
\text { (g) }\end{array}$ & $\begin{array}{c}\text { Berat } \\
\text { Basah } \\
(\mathrm{g})\end{array}$ & $\begin{array}{l}\text { Berat } \\
\text { kering } \\
\text { (g) }\end{array}$ & $\begin{array}{c}\text { Berat } \\
\text { Basah } \\
\text { (g) }\end{array}$ & $\begin{array}{l}\text { Berat } \\
\text { kering } \\
\text { (g) }\end{array}$ & $\begin{array}{c}\text { Berat } \\
\text { Basah } \\
\text { (g) }\end{array}$ & $\begin{array}{c}\text { Berat } \\
\text { Kering } \\
\text { (g) }\end{array}$ & \\
\hline 4 & Nappies & 333,78 & 61,06 & 333,19 & 78,18 & 333,16 & 45,19 & 333,5 & 47,99 & 17,43 \\
\hline 5 & Kayu & 332,68 & 243,93 & 333,28 & 260,79 & 333,12 & 260,15 & 333,3 & 282,62 & 78,61 \\
\hline 6 & Tekstil & 333,40 & 13,13 & 333,35 & 222,22 & 333,29 & 195,53 & 333,2 & 173,42 & 54,10 \\
\hline 7 & Karet/Kulit & 333,14 & 301,43 & 331,62 & 325,92 & 333,21 & 314,75 & 333,3 & 326,81 & 95,31 \\
\hline
\end{tabular}

\subsection{Fraksi Degradable Organic Carbon (DOC)}

Degradable Organic Carbon (DOC) adalah karbon organik yang terdapat dalam sampah dan dapat terurai secara biokimia (IPCC 2006GL). Fraksi DOC komponen dihitung dari perkalian fraksi berat sampah basah, fraksi kandungan bahan kering dan DOCi. DOCi adalah nilai default fraksi DOC untuk setiap jenis komponen (IPCC 2006GL). Fraksi DOC sampah merupakan jumlah dari DOC seluruh komponen. Berdasarkan hasil perhitungan, fraksi DOC sampah yang masuk ke TPA Tanjung Belit adalah $0,110 \mathrm{Gg} \mathrm{C} / \mathrm{Gg}$ sampah.

Tabel 7: Fraksi DOC Sampah yang Masuk ke TPA Tanjung Belit

\begin{tabular}{rlrrrr}
\hline No & Komponen Sampah & $\begin{array}{c}\text { Fraksi Berat } \\
\text { Sampah Basah }\end{array}$ & $\begin{array}{c}\text { Fraksi Kandungan } \\
\text { Bahan Kering }\end{array}$ & $\begin{array}{c}\text { DOCi } \\
\text { (Default) }\end{array}$ & \multicolumn{1}{c}{ DOC } \\
\hline 1 & Makanan & 0,495 & 0,212 & 0,380 & 0,040 \\
2 & Kertas/Karton & 0,115 & 0,586 & 0,440 & 0,030 \\
3 & Kebun dan Taman & 0,053 & 0,415 & 0,490 & 0,011 \\
4 & Nappies & 0,062 & 0,174 & 0,600 & 0,006 \\
5 & Kayu & 0,025 & 0,786 & 0,500 & 0,010 \\
6 & Tekstil & 0,033 & 0,541 & 0,300 & 0,005 \\
7 & Karet/Kulit & 0,017 & 0,470 & 0,008 \\
8 & Plastik & 0,131 & 1,000 & 0,000 & 0,000 \\
9 & Kaca & 0,019 & 1,000 & 0,000 & 0,000 \\
10 & Logam & 0,012 & 1,000 & 0,000 & 0,000 \\
11 & Lain-lain & 0,030 & 1,000 & 0,000 & 0,000 \\
\hline \multicolumn{7}{r}{ Fraksi DOC } \\
\hline
\end{tabular}

\subsection{Estimasi Jumlah DOC Sampah yang Masuk ke TPA Tanjung Belit}

Besar kandungan DOC sampah yang masuk ke TPA Tanjung Belit selama tahun 2015 diperkirakan dengan mengalikan fraksi DOC dan berat total sampah masuk. Berdasarkan hasil perkalian Fraksi DOC dan berat total sampah yang masuk selama tahun 2015 maka didapatkan bahwa total kandungan DOC adalah sebesar $0,585 \mathrm{Gg} \mathrm{C}$.

Tabel 8: Estimasi Jumlah DOC Sampah yang Masuk ke TPA Tanjung Belit

\begin{tabular}{ccccc}
\hline $\begin{array}{c}\text { Total Berat Sampah } \\
\text { Harian } \\
(\text { Ton })\end{array}$ & $\begin{array}{c}\text { Berat Sampah } \\
\text { tahunan } \\
\text { (Ton) }\end{array}$ & $\begin{array}{c}\text { Fraksi } \\
\text { DOC }\end{array}$ & & \multicolumn{2}{c}{ Kandungan DOC } \\
\cline { 4 - 5 } & $5.286,68$ & 0.110 & 585,48 & $(\mathrm{Gg} \mathrm{C})$ \\
\hline
\end{tabular}

\section{Kesimpulan}

Berdasarkan hasil survei dan pengolahan data terkait kegiatan estimasi kandungan DOC pada sampah padat kota yang masuk ke TPA Tanjung Belit selama tahun dapat disimpulkan sebagai berikut:

1. Berdasarkan hasil perhitungan didapatakan bahwa volume sampah yang masuk ke TPA Tanjung Belit berkisar antara $27,53-45,86 \mathrm{~m}^{3} /$ hari dengan rata-rata $42.4 \mathrm{~m}^{3} /$ hari. Sedangkan berat sampah 
berkisar antara $11.991,88-15.642,31$ ton/hari dengan rata-rata berat $14.594,05$ ton/hari. Jumlah volume sampah masuk pertahun diperkirakan sebesar $15490.6 \mathrm{~m}^{3}$ yang diperkirakan memiliki total berat sebesar 5.286,68 ton.

2. Berdasarkan hasil perhitungan terhadap komposisi sampah berdasarkan 11 komponen, maka diketahui bahwa sampah makanan merupakan sampah yang paling dominan di TPA Tanjung Belit yaitu sebesar 49,54 \% dari total sampah yang masuk setiap hari.

3. Komponen sampah dengan kandungan bahan kering tertinggi di TPA Tanjung Belit adalah sampah karet dan kulit dengan nilai fraksi 95,31\% sedangkan yang terendah adalah Sampah Nappies dengan nilai fraaksi sebesar $17,43 \%$.

4. Berdasarkan hasil perhitungan terhadap sampah di TPA Tanjung belit di dapatkan nilai fraksi DOC sebesar 0,110 .

5. Kandungan DOC pada sampah yang masuk di TPA Tanjung Belit selama tahun 2016 adalah sebesar 585,48 ton atau setara dengan $0,585 \mathrm{Gg} \mathrm{C}$.

\section{Ucapan Terima Kasih}

Terimakasih kami ucapkan kepada Lembaga Penelitian UIR yang telah memberikan kesempatan dan dukungan selama pelaksanaan penelitian, kepada Kementerian Lingkungan Hidup Republik Indonesia, Badan Lingkungan Hidup Provinsi Riau atas dukungan, saran dan masukan serta United Nation Development Program yang telah membantu pembiayaan penelitian ini.

\section{References}

BPS-Kabupaten Rokan Hulu, 2015. Kabupaten Rokan Hulu dalam Angka 2015. Badan Pusat Statistik Kabupaten Rokan Hulu, Indonesia

Gidarakos, E. Havas, G. Ntzamilis, P., 2005. Municipal Solid Waste Determination, Supporting The Integrated Solid Waste Management System in The Isldan of Crete, Laboratory of Toxic dan Hazardous Waste Management, Technical University of Crete, Greece 2005

IPCC (2006). 2006 IPCC Guide Lines for National Greenhouse Gas Inventories: Volume 5- Waste, Prepared by National Greenhouse Gas Inventories Programme, Engleston H. S., Buendia L., Miwa K., Ngara T. And Tanabe K. (eds). Published : IGES, Japan.

KLH-RI, 2012. Pedoman Penyelenggaraan Inventarisasi Gas Rumah Kaca Nasional Buku II Volume 4. Boer, R.,Gumilang, R., Siagian, U.WR., Ardiansyah, M., Surmaini, E.,Ridha, D. M., Gani, Mulkan., Rukmi, W.A., Gunawan, A., Utomo, P., Setiawan, G., Irwani, S., Parinderati, R. Published: Kementerian Lingkungan Hidup (KLH), Indonesia. 